\title{
R다대는 ESTADO, POLÍTICAS SEXUAIS E CIDADANIA LGBT NO BRASIL PÓS-IMPEACHMENT
}

\author{
Henrique Araujo Aragusuku ${ }^{1}$ \\ Maria Fernanda Aguilar Lara² \\ Yuri Fraccaroli ${ }^{3}$ \\ Alexandre Nogueira Martins ${ }^{4}$
}

\begin{abstract}
Resumo: Este artigo tem como objetivo principal a construção de uma análise conjuntural sobre as políticas sexuais no Brasil, com destaque para as políticas de cidadania LGBT no âmbito do Governo Federal. Nossa narrativa parte de uma análise histórica de tais políticas, concentrandose fundamentalmente no período de 1996 a 2018, ou seja, do momento de apresentação dos primeiros programas destinados à população LGBT pelo Governo Federal ao atual período de transição político-ideológica da agenda governamental em um Brasil pós-impeachment. Em termos teórico-metodológicos, realizamos uma análise conjuntural, vinculando eventos políticos fragmentados e dispersos em uma narrativa articulada, relacionando conceitos como política sexual e cidadania LGBT para a produção de uma análise do cenário político nacional. Buscamos assim evidenciar os principais fatos políticos que marcaram as relações entre o Estado brasileiro e a sociedade civil no campo das políticas sexuais. Cabe ressaltar que esta narrativa não se conformou enquanto uma análise acabada ou fechada, mas sim como uma possibilidade analítica que intenta trazer novos elementos para refletirmos sobre o contexto político-social brasileiro. Por outro lado, trata-se de uma contribuição teórica ao campo de estudos de gênero e sexualidade, em específico, ao campo de estudos sobre Estado e políticas sexuais.
\end{abstract}

Palavras-chave: Políticas Sexuais; Gênero; Cidadania LGBT; Governo Federal.

\section{Introdução}

As políticas sexuais, sobretudo a recente arena de políticas de cidadania LGBT, são um alvo de constantes ataques de grupos religiosos fundamentalistas e de um conservadorismo cristão que se rearticula nos países ocidentais (DEFAGO; FAÚNDES; VAGGIONE, 2018; KOVÁTS; PÕIM, 2015). Tais grupos se opõem radicalmente às políticas de direitos sexuais emergentes ao longo do século XXI; questões como o direito ao aborto, a normalização jurídica

\footnotetext{
${ }^{1}$ Doutorando e Mestre em Psicologia Social e Especialista em Psicologia Política pela Universidade de São Paulo. Graduado em Psicologia pela Universidade Federal de Mato Grosso. Bolsista CNPq.

2 Doutoranda e Mestre em Psicologia Social pela Universidade de São Paulo. Graduada em Psicologia pela Universidade Federal de Mato Grosso.

${ }^{3}$ Mestre em Psicologia Social e Graduado em Gestão de Políticas Públicas pela Universidade de São Paulo.

${ }^{4}$ Mestrando em Sociologia e Bacharel em Ciências Sociais pela Universidade de São Paulo.

Vol. 02, N. 04, Out. - Dez., 2019 - www.revistas.unilab.edu.br/index.php/rebeh
} 
das uniões homoafetivas e da adoção homoparental, o reconhecimento público das identidades trans, a educação sexual e o acesso a métodos contraceptivos e preventivos de DST/AIDS são frontalmente rejeitadas sob o argumento da defesa da família, da cultura ocidental e dos valores cristãos. Notoriamente, o combate à "ideologia de gênero" representa nos dias atuais a principal investida política destes grupos conservadores, proporcionando uma unificação discursiva das ações de combate às políticas de direitos sexuais (ARAGUSUKU, 2018; JUNQUEIRA, 2017; MACHADO, M., 2018; MISKOLCI; CAMPANA, 2017).

No contexto brasileiro, vivemos hoje os efeitos da maior crise política a perpassar o país desde a redemocratização e a instituição da Nova República em 1985. Em 2016, tivemos o impeachment de Dilma Rousseff (PT) da Presidência da República, e a queda de um Presidente da Câmara dos Deputados, o ex-deputado Eduardo Cunha (PMDB/RJ), posteriormente preso por desvio de recursos públicos. Em 2018, presenciamos a prisão de Lula (PT) - candidato que liderava as pesquisas de intenção de voto para presidente - condenado em segunda instância por corrupção e lavagem de dinheiro no âmbito da Operação Lava Jato, em um julgamento marcado por polêmicas, manipulações jurídicas e arbitrariedades. Algo que foi seguido pela emergência eleitoral de Jair Bolsonaro (PSL), candidato da extrema-direita conhecido por suas posições conservadoras e sua defesa pública à Ditadura Civil-Militar, que no início do processo eleitoral ainda possuía pouco apoio das elites políticas e econômicas. O então deputado e outsider do mainstream político venceu o segundo turno das eleições contra Fernando Haddad (PT) em novembro de 2018, em uma campanha permeada por polêmicas e pela circulação massiva de notícias falsas (as chamadas "fake news").

A forte crise política que abalou o país com o impeachment de Dilma Rousseff em 2016 - agravada pelas manifestações massivas de rua, pelo desenrolar da Operação Lava Jato e pela crise econômica, que acumulou um recuo de aproximadamente $7,5 \%$ do PIB no período entre 2015 e 2016 (IBGE, 2017) - fortaleceu os grupos conservadores e de extrema-direita no Brasil, que ganharam importantes espaços sociais e políticos, impulsionando assim uma forte agenda moral, proposta enquanto resposta e solução à crise institucional.

Em meio a todo esse cenário de crise política e institucional, o que temos para discorrer sobre políticas sexuais e políticas LGBT? Como a conjuntura política e social se relaciona com as pautas em torno da sexualidade? Em muitos momentos quando os fenômenos da "grande política" são tratados pela literatura acadêmica, tal temática é vista como secundária ou insignificante, restrita a seu respectivo nicho de movimentos sociais e grupos de pesquisa. Entretanto, tal apagamento produz uma visão parcial da realidade que ignora a dominação 
masculina e heteronormativa da sociedade brasileira. Desse modo, como podemos redirecionar o olhar sobre a política nacional, vinculando os principais eventos políticos da atualidade com as políticas da sexualidade? Como podemos "sexualizar" a "grande política"?

Assim, buscou-se levantar algumas reflexões sobre as relações entre Estado e cidadania LGBT no Brasil, principalmente a partir da análise das ações do Governo Federal, visualizando o atual momento de avanço do conservadorismo político, de fragilização democrática e crise institucional após o impeachment de Dilma Rousseff. Nos atentamos a uma visão conjuntural desse fenômeno, relacionando eventos dispersos na construção de uma narrativa mais acabada e coesa, porém em hipótese alguma fechada - são muitas as lacunas existentes, que podem ser preenchidas por eventos aqui esquecidos ou omitidos.

Por fim, este artigo foi dividido em três partes, ou subtópicos. A primeira buscou delimitar o arcabouço conceitual que permeia nossa narrativa sobre a trajetória das políticas sexuais no Brasil. A segunda realizou um levantamento histórico das políticas de cidadania LGBT impulsionadas pelo Governo Federal, de 1996 a 2016, propondo uma análise crítica deste processo histórico. Enquanto que a terceira trouxe uma leitura do período do governo Temer (2016-2018), analisando as contraditórias relações de seu governo com as políticas de direitos sexuais e cidadania LGBT.

\section{Políticas sexuais e cidadania LGBT no Brasil: considerações teórico-metodológicas e conceituais}

Podemos considerar que o Brasil do século XXI é perpassado por relações mais flexíveis e instáveis entre o Estado e as políticas sexuais - algo que se reflete, por exemplo, na consolidação de uma ampla rede de políticas públicas voltada para a promoção de cidadania LGBT. No entanto, tais relações são bastante recentes e ainda precárias. Não é novidade constatarmos que o Estado brasileiro possui um longo histórico de ações repressivas voltadas aos sujeitos que se afastam dos padrões impostos pela heteronormatividade - da aplicação dos códigos canônicos, promovidos pela Igreja Católica desde a colonização, ao combate às patologias sexuais definidas pelos saberes psi e biomédicos a partir do século XIX (FIGARI, 2007; GREEN, 2000; TREVISAN, 2000). Desse modo, o Estado brasileiro historicamente atendeu às demandas repressivas de determinados grupos dentro do campo das políticas sexuais, assumindo um papel de promotor da regulação e normatização das práticas sexuais, visando a supressão e o controle dos corpos "desviantes". 
Particularmente em relação ao contexto mais recente (século XX) e mais diretamente relacionado ao escopo do presente artigo, é interessante retomarmos certas racionalidades políticas que permearam as produções legislativas do Estado brasileiro e as ações políticas que jdelas derivaram. Diferente de outras experiências sul-americanas, o Estado Brasileiro não formalizou legislações específicas que proibissem explicitamente o chamado "homossexualismo" - apesar de ter existido uma tentativa de inclusão durante a reforma do Código Penal no período do Estado Novo, em 1940. Entretanto, isso de forma alguma significou um abrandamento no tratamento dos sujeitos "desviantes" por parte das forças de coerção social, que se utilizaram de pontos ambíguos do Código Penal desde 1830, como a criminalização do "atentado ao pudor", para promover perseguições e ações repressivas (GREEN, 2000; GREEN; POLITO, 2006).

A partir de meados do século XX, novas formações sociais entraram em cena, com o agenciamento de novas subjetividades a partir das lutas sexuais, junto à emergência dos movimentos feministas e das subculturas homossexuais (WEEKS, 1989, 2002). Gradualmente, as disputas no campo das políticas sexuais foram provocando transformações mais significativas na sociedade brasileira como um todo, tendo como marco o período de fim dos anos 1970, em confluência à emergência dos movimentos pela redemocratização do país, após mais de quinze anos de ditadura militar (CRUZ, 2015; GREEN, 2000; FACCHINI, 2005; TREVISAN, 2000). Dentro deste caldo das lutas democráticas, surgiu o movimento homossexual brasileiro, que passou a produzir campanhas pelo reconhecimento da homossexualidade enquanto uma expressão sexual legítima e, consequentemente, politizando a sexualidade, trazendo-a para o campo da cidadania e dos direitos humanos.

A percepção do contexto sócio-histórico brasileiro de fins do século XX, enxergado por meio das lentes da análise das políticas da sexualidade (RUBIN, 1984; WEEKS, 1989), mais do que enfatizar o sofrimento e as experiências de violência e humilhação social vivenciadas por esses corpos "desviantes", certamente nos possibilitou também explicitar os processos que perpassam as relações entre o Estado e a sociedade civil. Partimos, assim, de uma produção de conhecimento ancorada em saberes localizados (HARAWAY, 1995) - ou seja, saberes politicamente posicionados e distantes de uma pretensa neutralidade científica. Desse modo, tal reflexão nos permite esboçar linhas de análise para compreendermos não apenas o contexto de cidadania precária (BENTO, 2014) vivenciada pelas populações LGBT, mas também a situação de outros setores da população que experienciam e se identificam pela condição de precariedade (BUTLER, 2018). 
Mesmo conscientes dos limites políticos da identidade, questionados desde a formação do movimento homossexual brasileiro (MACRAE, [1982] 2018), seria imprudente negar os avanços políticos e sociais conquistados nesta trajetória, principalmente ao considerarmos o papel central que a instituição da representação tem nos sistemas democráticos ocidentais contemporâneos (BUTLER, 2015). Entretanto, mais recentemente, os limites desses avanços, conquistados principalmente via Poder Judiciário (FRACCAROLI; HEINZELMANN, 2018), passaram a sofrer o que entendemos como uma dupla crítica: (I) por um lado, vêm se desenhando problematizações e críticas quanto ao avanço e aos limites de inclusão/representatividade (BUTLER, 2003) e as reais possibilidades de mudança social por parte dos mecanismos juridicamente propostos; (II) por outro lado, em consonância ao caráter fragmentário, de natureza stop-and-go e pouco institucionalizado das políticas LGBT, indagase sobre as possibilidades de permanência destas ao longo do tempo e se não estaria se desenhando uma cidadania de tipo distintivo.

Neste sentido, Berenice Bento (2014) apontou a "cidadania precária" como a condição de não-cidadania vivenciada historicamente por mulheres, negros/as e LGBT no Brasil condição que, para a autora, representa uma dupla negação: a negação de habitar o humano e a negação de ser cidadão. Nesse sentido, "o reconhecimento político, econômico e social foi (e continua sendo) lento e descontínuo" (BENTO, 2014, p. 167), marcado por idas e vindas e pela instabilidade das condições de cidadania. Em paralelo a esse padrão cultural da política sexual brasileira identificado por Bento, vale a pena recordar a leitura de Guacira Louro sobre uma suposta "reação" aos tímidos avanços conquistados; certamente, uma dimensão contemporânea dessa cidadania precária:

Se, por um lado, alguns setores sociais passam a demonstrar uma crescente aceitação da pluralidade sexual e, até mesmo, passam a consumir alguns de seus produtos culturais, por outro lado, setores tradicionais renovam (e recrudescem) seus ataques, realizando desde campanhas de retomada dos valores tradicionais da família até manifestações de extrema agressão e violência física (LOURO, 2008, p. 242).

Em síntese, ainda que as dimensões de gênero e sexualidade continuem sendo compreendidas como um recorte dissonante ou menos válido daqueles hegemonicamente utilizados para analisar a high politics (SCOTT, 1995) - ou a "grande política"- tais dimensões podem permitir a construção de análises conjunturais mais amplas. Se no atual momento político brasileiro gênero, sexualidade e raça tem se tornado categorias centrais, por que não 
seriam em um contexto passado, mais fortemente marcado pela violência homofóbica, misógina, racista e sexista?

Concomitantemente, o conceito de "política sexual", desenvolvido por diversos/as jautores/as (CARRARA, 2015; RUBIN, 1984; WEEKS, 1989), nos proporciona uma importante ferramenta conceitual para pensarmos sobre as relações entre política e sexualidade nas sociedades contemporâneas. Construindo uma síntese da noção de política sexual, Sérgio Carrara (2015) apresentou que:

(...) este conceito possibilita a abordagem conjunta de diferentes tipos de ação social dirigidos ao Estado ou promovidos em seu âmbito ou sob sua chancela (...). O conceito de política sexual, deste modo, interpela simultaneamente múltiplas dimensões da gestão social do erótico e do sexual e explora a coexistência, às vezes conflitiva, de distintos e muitas vezes contraditórios estilos de regulação moral, compreendidos aqui como conjuntos singulares de técnicas de produção de sujeitos, ou seja, de pessoas dotadas de certa concepção de si e de certa corporalidade (CARRARA, 2015, p. 234-235).

Em nossa compreensão, o Estado é uma esfera privilegiada de poder que atua sobre a regulamentação, estabilização e manutenção de determinados ordenamentos socioculturais e políticos e, consequentemente, influi sobre as políticas sexuais (CONNELL, 1990; WEEKS, 1989). Por outro lado, as estruturas do Estado são condicionadas pelos movimentos dinâmicos e em muitos momentos conflitivos da sociedade civil, passando por constantes transformações ao longo da história. Assim, o aparelho estatal não pode ser analisado enquanto um bloco monolítico que representa apenas uma única lógica discursiva, mas como um campo poroso e permeável, conformado por disputas e relações conflituosas (LAVELLE, SZWAKO, 2015). Logicamente, tal conformação é perpassada por relações de poder que condicionam o grau de abertura e porosidade do aparelho estatal - de formações ditatoriais que privilegiam grupos restritos no poder a formações democráticas que garantem espaços mínimos de disputa políticoideológica.

Para Raewyn Connell (1990), por exemplo, nos momentos em que o Estado se fecha em estruturas rígidas e ditatoriais, impondo a ordem por meio do uso da coerção e da repressão, é fortalecido o caráter "masculino" da gerência do aparelho estatal, vinculado à divisão de gênero do mundo do trabalho comumente estabelecida nas sociedades contemporâneas. Em sua compreensão, "a diretoria do Estado ("elites" da política, a burocracia, o judiciário, os militares) quase em todos os lugares do mundo é composta de 95 a 100 por cento de homens. O aparato coercitivo do Estado (polícia, militares, oficiais das prisões) possui uma porcentagem considerável de homens" (CONNELL, 1990, p. 523, tradução nossa). Enquanto que as Vol. 02, N. 04, Out. - Dez., 2019 - www.revistas.unilab.edu.br/index.php/rebeh 
mulheres são alocadas majoritariamente em espaços de serviços humanos (escolas, hospitais, etc.) ou na direção de subsecretarias.

Neste sentido, as disputas em torno das políticas sexuais perpassam também a divisão jesigual de poder entre homens e mulheres, junto a normalização das hierarquias e das performances de gênero no padrão heteronormativo. Assim, processos de democratização podem favorecer o questionamento de tais desigualdades e hierarquias, enquanto que processos autoritários e ditatoriais tendem a naturalizar os ordenamentos socioculturais e políticos instituídos.

Em certos períodos históricos, como o momento em que vivemos atualmente, a sexualidade e o campo das políticas sexuais se tornam ainda mais contestados e politizados na esfera pública, a partir das constantes renegociações em torno da vida erótica - algo que Gayle Rubin (1984) conceituou como "guerras sexuais". Nestes momentos, acirram-se as lutas em torno dos direitos sexuais, compreendidos aqui enquanto "prerrogativas legais relativas ou à sexualidade ou a grupos sociais cujas identidades foram forjadas sobre formas específicas de desejos e de práticas sexuais" (CARRARA, 2010, p. 135), assim como se avolumam as reações políticas de grupos conservadores à desestabilização das normativas sexuais historicamente instituídas.

\section{As políticas de cidadania LGBT na agenda do Governo Federal: surgimento, ampliação e declínio (1996-2016)}

Apesar de presenciarmos desde os anos de 1980 a conformação de uma agenda de reivindicação de direitos sexuais, as primeiras políticas direcionadas para as populações LGBT no Brasil, para além do âmbito da saúde pública e da epidemia da HIV/AIDS, articularam-se apenas em fins dos anos 1990 (CARRARA; VIANNA, 2008; RAMOS; CARRARA, 2006). A década de 1990 foi um período de expansão da articulação política dos movimentos LGBT, que se institucionalizavam em um processo de diálogo com outros grupos da sociedade civil (como partidos políticos, associações profissionais, entidades de classe, etc.) e com atores do poder público, propiciando o avanço do reconhecimento de suas demandas em termos de ações governamentais e políticas públicas.

Neste período, presenciamos eventos marcantes como a criação da primeira associação nacional de grupos LGBT, em 1995, a então Associação Brasileira de Gays, Lésbicas e Transexuais (ABGLT); a realização da $17^{\text {a }}$ Conferência Mundial da International Lesbian and 
Gay Association (ILGA) ${ }^{5}$, também em 1995, na cidade do Rio de Janeiro; o surgimento das primeiras manifestações públicas e paradas do orgulho (1995, Curitiba e Rio de Janeiro; 1996, São Paulo; 1997, São Paulo); e a instituição da primeira política pública destinada ao combate à homofobia, o Disque Defesa Homossexual (DDH) e o Centro de Referência contra a Discriminação das Minorias Sexuais no Estado do Rio de Janeiro, em 1999 (FACCHINI, 2005; RAMOS; CARRARA, 2006; RAMOS; PEREIRA, 1999). Tais eventos foram apenas o prelúdio dos anos 2000, momento em que as demandas dos movimentos LGBT se tornaram ainda mais relevantes na opinião pública e nas as agendas governamentais.

No âmbito do Governo Federal, o governo de Fernando Henrique Cardoso (1995-2002), do Partido da Social Democracia Brasileira (PSDB), na publicação do Programa Nacional de Direitos Humanos (PNDH), em 1996, citou pela primeira vez o termo "homossexuais" em um documento oficial de grande circulação, enquanto um grupo "em situação mais vulnerável”, público alvo de políticas de direitos humanos (BRASIL, 1996). Iniciava-se assim um período de ampliação do diálogo de parte do poder público federal com os movimentos LGBT, visualizando a construção de ações governamentais e políticas públicas destinadas a este grupo social.

A segunda edição do PNDH - publicada em fins do segundo mandato de FHC, em 2002 - fortaleceu a perspectiva da cidadania e direitos sexuais, sendo destacada no documento uma sessão exclusiva de políticas destinadas para "Gay, Lésbicas, Travestis, Transexuais e Bissexuais - GLTTB". Nas palavras do então presidente: "Inserimos, na pauta das políticas públicas, questões que até pouco tempo atrás eram consideradas tabus ou não recebiam a devida atenção, como a dos direitos dos homossexuais" (BRASIL, 2002). Entretanto, apesar de presenciamos diversos avanços no campo dos direitos humanos, o governo FHC aplicava um programa político alinhado às premissas econômicas do neoliberalismo.

Se compreendemos o neoliberalismo enquanto um projeto político propagado pelas elites econômicas, cujo objetivo é reorganizar o modelo de acumulação de capital, temos como pontos centrais a proliferação de medidas de "acumulação por despossessão" (ou seja, acumulação de capital por determinadas classes a partir despossessão e exclusão de outras), a expansão da privatização e da mercantilização, a financeirização da sociedade, a gestão de crises de modo a redistribuir a riqueza em direção às classe mais privilegiadas e aos países mais

\footnotetext{
${ }^{5}$ Importante ressaltar que com a pluralização das identidades e demandas específicas, atualmente, a ABGLT se chama oficialmente Associação Brasileira de Lésbicas, Gays, Bissexuais, Travestis, Transexuais e Intersexos; e a ILGA, International Lesbian, Gay, Bisexual, Trans and Intersex Association.

Vol. 02, N. 04, Out. - Dez., 2019 - www.revistas.unilab.edu.br/index.php/rebeh
} 
ricos - de modo que o próprio Estado atua como um agente dessa redistribuição que constrói e fortalece o poder das classes dominantes (HARVEY, 2007; 2011).

Nesta acepção de neoliberalismo, certamente o governo FHC pode ser caracterizado como um governo neoliberal ao adotar uma agenda que garante a livre circulação e a valorização de capitais financeiros no país, com a realização de grandes privatizações, a flexibilização de direitos trabalhistas, a instituição da Lei de Responsabilidade Fiscal e a diminuição da capacidade do Estado na execução políticas sociais (PAULANI, 2006). Cabe destacar que, a partir do segundo mandato de $\mathrm{FHC} \mathrm{-} \mathrm{perpassado} \mathrm{por} \mathrm{uma} \mathrm{forte} \mathrm{crise} \mathrm{econômica}$ - as medidas neoliberais caíram em grande descrédito popular, abrindo caminhos para a vitória de Lula em 2002 e a chegada inédita de um partido de esquerda, até então crítico à retórica neoliberal, ao Governo Federal no período da Nova República.

Apesar das mudanças em algumas políticas macroeconômicas e geopolíticas em relação ao governo anterior, o Governo Lula (2002-2010) manteve algumas prerrogativas básicas do neoliberalismo e assumiu um discurso pró-mercado, sob o argumento da garantia da governabilidade e do crescimento econômico, estabelecendo algumas continuidades em relação ao governo anterior (ANDERSON, 2011; OLIVEIRA; BRAGA, RIZEK, 2010). Sob um discurso de estado de exceção (que se tornaria regra), se justificou a continuidade do projeto neoliberal como uma "necessidade" para a garantia da estabilidade fiscal e do crescimento econômico (PAULANI, 2006). Temos, como exemplos, a nomeação de Henrique Meirelles (atualmente, MDB/SP) - naquele momento, deputado federal eleito pelo PSDB - na direção do Banco Central; a realização da reforma da previdência de 2003, que resultou na divisão do PT e na ruptura de sua ala mais à esquerda com o partido; e a ampliação das concessões de serviços públicos para a iniciativa privada, contribuindo para a consolidação do regime de parcerias público-privadas como modelo de gestão pública no país.

Por outro lado, foi durante o Governo Lula que presenciamos os principais avanços concretos dentro do campo das políticas LGBT no Brasil, com a implementação de ações governamentais em âmbito federal que impulsionaram a consolidação de políticas públicas também em nível estadual e municipal (ARAGUSUKU; LOPES, 2016, 2018; MELLO, BRITO; MAROJA, 2012; CARRARA, 2010; CARRARA; VIANNA, 2008). Os programas acumulados de 2004 (com a publicação do Brasil Sem Homofobia) a 2010 (com a criação do Conselho Nacional LGBT) foram intitulados por Luiz Mello, Daniela Maroja e Walderes Brito (2010) como talvez "o melhor conjunto de propostas de políticas públicas para transexuais, travestis, bissexuais, gays e lésbicas em todo o mundo" (p. 56), apesar das fragilidades e 
incertezas em relação a sua implementação efetiva. Assim, compreendemos que a primeira década do século XXI foi perpassada por um salto no avanço das pautas LGBT dentro das agendas governamentais em todo o Brasil, com um forte protagonismo do Governo Federal na propagação de tais políticas.

No entanto, como discorreu Bruna Irineu (2014), o avanço das políticas LGBT no Brasil e no mundo se deu em um momento de hegemonia do neoliberalismo enquanto modelo societal e político-econômico. Dessa forma, o acesso à cidadania por parte das populações LGBT envolveu também capturas conservadoras e normalizações, pois as demandas por direitos sexuais foram progressivamente adaptadas a ordenamentos de exclusão e dominação social. Concomitantemente, com o processo de avanço da cidadania LGBT no Brasil, durante as articulações entre governos e movimentos sociais, presenciamos a emergência de uma afirmação excessiva do "familismo" enquanto ethos moral e de uma "homofobia cordial" como forma comum das negociações político-institucionais. Por "familismo", entende-se uma moral sexual condicionada pela heteronormatividade e pelos valores do cristianismo e, por "homofobia cordial", as contradições da governabilidade de coalizão, que envolvem a negociação mútua com atores sociais antagônicos dentro do campo das políticas sexuais, visando a manutenção do governo e dos grupos no poder (IRINEU, 2017).

Ademais, tanto as políticas demandadas por parte do movimento LGBT, quanto as políticas sexuais implementadas pelos governos FHC e Lula foram constituídas no âmbito de uma racionalidade neoliberal - como defendeu Rafael Toitio (2016), tratando sobre os posicionamentos e discursos proferidos pela ABGLT nos últimos dez anos. Partindo das reflexões de Pierre Dardot e Christian Laval (2016, p. 17), podemos compreender o neoliberalismo não apenas como um sistema econômico de produção, mas um sistema antropológico que produz subjetividades condicionadas pela racionalidade do capitalismo contemporâneo, cuja principal característica consiste na generalização da "concorrência" como norma de conduta e da "empresa" como modelo de subjetivação. Consequentemente, este processo de inclusão pelo consumo, pela privatização e pela racionalidade neoliberal nos proporcionou uma "cidadania de consolação", como destacado por João de Oliveira (2013), resultando "uma cidadania vivida na consolação do privado pelos agravos produzidos pela discriminação do público" (OLIVEIRA, 2013, p. 75).

Adentrando na esfera dialógica entre Estado e sociedade civil, Frederico Machado (2013) analisou as relações entre o Governo Federal e os movimentos LGBT no Brasil, enfocando os aspectos discursivos que permearam as políticas públicas impulsionadas durante 
o Governo Lula (2003-2010). Na sua concepção, a entrada dos movimentos LGBT nas esferas do Estado, principalmente através das políticas de participação social (como os conselhos e as conferências), provocou em determinado grau um processo de adaptação de tais movimentos à hormatividade da lógica estatal.

Paralelamente, presenciamos a propagação dos discursos do "participacionismo" e do “diferencialismo identitário", com a cristalização e essencialização das diferenças identitárias entre distintos grupos, que passam a competir por espaços na agenda governamental. Em confluência a isso, temos a constituição de um discurso de apaziguamento dos conflitos sociais, despolitizando a atuação desses movimentos. Neste sentido, a lógica estatal impôs a regulação do inconformismo a partir da adaptação dos movimentos LGBT às normas da política de participação social - impossibilitando assim a emergência do "político" no sentido da instância do dissenso e do conflito (MACHADO, F., 2013).

Podemos considerar também que os governos petistas não conseguiram se esquivar do que Nancy Fraser (2017) intitulou de "neoliberalismo progressista"6, ou seja, a aliança de políticas de direitos humanos com políticas econômicas neoliberais. Nas palavras da autora, uma mistura de "ideias truncadas de emancipação com formas letais de financeirização". No Brasil, como apresentamos anteriormente, essa junção entre políticas econômicas neoliberais e políticas de direitos humanos perpassou o Governo Lula em seu fundamento.

O "neoliberalismo progressista", no entanto, possui uma contradição basilar: as possibilidades materiais de realização das políticas de direitos humanos (dentre os quais, os direitos sexuais) são minadas pelos próprios termos neoliberais em que são formuladas - dado que o neoliberalismo enquanto projeto político e enquanto racionalidade se fundamenta não na construção de condições igualitárias, mas no aprofundamento das desigualdades sociais e na precarização das condições em que se exerce a cidadania (HARVEY, 2007; DARDOT; LAVAL, 2016).

No Brasil, a partir das eleições de 2010, tivemos uma marcante rearticulação do campo do conservadorismo sexual, com o fortalecimento de lideranças religiosas conservadoras que passaram a atuar de forma mais organizada contra os avanços que vinham sendo alcançados no campo dos direitos sexuais (ALMEIDA, 2017; ARAGUSUKU, 2018; VITAL; LOPES, 2013).

\footnotetext{
${ }^{6}$ Embora Fraser (2017) tenho cunhado o termo para se contrapor às políticas adotadas pelo Partido Democrata ao "populismo reacionário" de Donald Trump, compreendemos que alguns paralelos podem ser realizados com a realidade brasileira. Logicamente, tais paralelos devem ser interpretados com cuidado. Em nossa concepção, o atual momento brasileiro se desvincula de um "neoliberalismo progressista", considerando que tais políticas seguem alinhadas ao projeto político-econômico neoliberal e, consequentemente, com a racionalidade neoliberal. Porém agora existe um neoliberalismo com uma roupagem populista e conservadora. Vol. 02, N. 04, Out. - Dez., $2019 \cdot$ www.revistas.unilab.edu.br/index.php/rebeh
} 
Frente ao polêmico debate sobre o aborto e sobre o casamento civil igualitário, a campanha de Dilma Rousseff fez grandes esforços para conquistar o apoio das lideranças evangélicas conservadoras, como quando lançou a "Carta aberta ao povo de Deus", na qual se comprometeu ja deixar para o Congresso Nacional "a função básica de encontrar o ponto de equilíbrio nas posições que envolvam valores éticos e fundamentais, muitas vezes contraditórios" ", como os temas do aborto, da família e da união estável (MACHADO, M., 2012). Por conta dessa estratégia, lideranças políticas ultraconservadoras, como os pastores Marco Feliciano e Eduardo Cunha, declararam apoio à Dilma.

Esta posição ambígua e o comprometimento político de Dilma Rousseff com grupos antagônicos - dialogando tanto com movimentos sociais feministas e LGBTs, quanto com grupos religiosos conservadores - gerou grandes problemas para o governo, que em seus primeiros meses já passava pela primeira crise relacionada a sua base parlamentar evangélica. Neste sentido, a Câmara dos Deputados, a partir da 54ª Legislatura (2011-2015), tornou-se um campo de batalha moral contra os avanços em direitos sexuais, protagonizada principalmente pela fortalecida bancada evangélica e por outros agrupamentos parlamentares conservadores (ARAGUSUKU, 2018)

Embora o foco deste artigo seja fundamentalmente a análise das políticas sexuais no Poder Executivo Federal, cabe pontuar que apesar de termos, desde os anos 1990, a proposição de diversos projetos de lei sobre direitos sexuais para a população LGBT (ANIS, 2007), tivemos somente um projeto legislativo aprovado pelo Congresso Nacional - a Lei Maria da Penha, sancionada em 2006, cuja redação contém a expressão “orientação sexual”. Tal cenário indica não apenas a presença de resistências entre os grupos parlamentares, mas também a falta de prioridade política das coalizões governamentais no estabelecimento de marcos jurídicos para a constituição de uma cidadania LGBT no Brasil.

Por outro lado, o Poder Judiciário foi responsável pelos principais avanços em termos de cidadania LGBT, tendo em vista a morosidade e a resistência do Legislativo, sendo emblemáticos o reconhecimento da união civil pelo Superior Tribunal de Justiça (STJ), em 2011; o estabelecimento do casamento homoafetivo pelo Supremo Tribunal Federal (STF), em 2013; e decisão pela não necessidade de laudos médicos para a alteração do nome e do registro de nascimento, também pelo STF, em 2018. Assim, podemos apresentar que, dentro da trama

7 Retirado do panfleto original "Carta aberta ao povo de Deus". Disponível em: https://www.gospelprime.com.br/carta-aberta-ao-povo-de-deus-confira-na-integra-as-palavras-de-dilmarousseff/. Acesso em 14 de março de 2018.

Vol. 02, N. 04, Out. - Dez., 2019 - www.revistas.unilab.edu.br/index.php/rebeh 
de relações institucionais e políticas, as decisões e debates jurídicos em relação às políticas sexuais influenciam também os rumos do Governo Federal.

Em paralelo ao reconhecimento pelo STF da legalidade da união civil homoafetiva, em 2011, parlamentares e lideranças conservadoras no Congresso Nacional se mobilizavam contra as políticas sexuais em curso (TOITIO, 2016). Sua mobilização central constituiu-se na campanha contra o "kit gay", em referência aos materiais preliminares do Programa Escola Sem Homofobia, que seriam utilizados como material didático nas escolas. Recorrendo a protestos parlamentares e à chantagem de não abrir inquérito contra o então Ministro da Casa Civil, Antonio Palocci (PT/SP), os grupos conservadores lograram que o governo recuasse em sua proposição. Inclusive, Dilma Rousseff, em entrevista à Rede Globo, chegou a declarar que não aprovava tais materiais, complementando que seu governo não faria "propaganda de opções sexuais"

Posteriormente, em 2013, presenciamos a crise desencadeada pela posse de Marco Feliciano (no período, PSC/SP) na presidência da Comissão de Direitos Humanos e Minorias (CDHM) da Câmara Federal. Naquele momento, era discutido o PDC 234/11, do Dep. João Campos (PRB/GO), que visava sustar parágrafos da Resolução 01/99 do Conselho Federal de Psicologia, permitindo que psicólogos/as afirmem que a homossexualidade seria uma patologia. Feliciano, além de defender abertamente tal projeto legislativo, também era acusado de racismo, devido a pronunciamentos realizados nas redes sociais, em anos anteriores. Desse modo, a presença de Feliciano na presidência da CDHM gerou uma série de protestos em todo o país, protagonizados pelos movimentos LGBT e feministas, que provocaram tensões e conflitos nas primeiras reuniões da CDHM naquele ano.

Os conflitos gerados causaram uma cisão irreparável entre políticos evangélicos (conservadores) e as políticas de direitos humanos promovidas pelo Governo Federal no campo do gênero e da sexualidade. Se antes os antagonismos eram latentes e todos compunham a mesma coalizão parlamentar; a partir daquele momento, as tensões em torno das políticas sexuais se tornavam uma verdadeira cruzada moral para os parlamentares do polo conservador, um campo de guerra sexual (RUBIN, 1984).

Como declarado por Marco Feliciano - em entrevista ao jornal Folha de São Paulo, em 2 de abril de 2013 - na sua opinião, os conflitos em torno da CDHM foram uma verdadeira traição do PT, uma quebra de compromissos e acordos feitos durante a campanha presidencial:

\footnotetext{
${ }^{8}$ Portal G1 (2011), "Governo não fará 'propagando de opção sexual', diz Dilma sobre kit", disponível em: http://g1.globo.com/educacao/noticia/2011/05/governo-nao-fara-propaganda-de-opcao-sexual-diz-dilma-sobrekit.html. Acesso em 10 de março de 2018. Vol. 02, N. 04, Out. - Dez., 2019 · www.revistas.unilab.edu.br/index.php/rebeh
} 
Então, por aquele momento ter os dois que pensavam sobre o aborto e ela assinando o documento dizendo que durante seu governo o aborto não seria tratado, fiquei com ela. Criei, na época uma central de inteligência via internet. Disparei quase 10 milhões de e-mails para todo o Brasil. Vesti a camisa, coloquei "Sou Dilma", né? E, de repente, dois anos e meio depois, temos aí essa problemática criada num jogo político".

Um outro acontecimento importante que precisa ser relembrado, é o impacto que as manifestações de junho de 2013 tiveram sobre a popularidade do governo, quando milhares de pessoas foram para as ruas de todo o país denunciar a precarização de suas vidas e a degradação dos serviços públicos, intensificando a crise de representatividade que cerca as instituições públicas e o sistema partidário brasileiro (VAINER et al., 2013). Com o fim do apaziguamento social e da quebra de hegemonia do projeto de conciliação de classes que marcou os governos petistas, a governabilidade de coalizão começou a apresentar rachaduras, e a gestão dos antagonismos se tornou mais complexa e difícil.

No ano seguinte, em 2014, tivemos uma forte articulação de grupos e lideranças conservadoras no Congresso Nacional em torno da tramitação do Plano Nacional de Educação (PNE), que foi aprovado sem a inclusão dos debates sobre "identidade de gênero" e "orientação sexual". Foi a partir deste momento que o discurso da "ideologia de gênero" passou a ser replicado de forma generalizada nas disputas legislativas (ARAGUSUKU, 2018; MIGUEL, 2016). De forma simplificada, tal conceito apresenta que os desenvolvimentos acadêmicos oriundos dos estudos feministas e LGBT são conhecimentos “ideológicos" e, consequentemente, falsos; em contrapartida a uma verdade biológica ou mesmo bíblica (JUNQUEIRA, 2017; MACHADO, M., 2018). Como resultado desse recuo no PNE, no ano seguinte, em 2015, diversos grupos conservadores lotaram as Câmaras de Vereadores e as Assembleias Legislativas de todo o país para a votação dos Planos Municipais e Estaduais de Educação. Evocaram palavras de ordem em "defesa da família” e contra a "doutrinação nas escolas", influenciando decisivamente o posicionamento de parlamentares nas votações dos planos de educação municipais e estaduais.

Com o avanço do conservadorismo cristão no Congresso Nacional - que conseguiu impor sua agenda política de retrocessos no campo das políticas sexuais no âmbito legislativo - presenciamos também um recuo das políticas sexuais do Governo Federal, que passou a

9 Entrevista realizada pela seção "Poder e Política" da Folha/UOL, disponível em: http://www1.folha.uol.com.br/poder/poderepolitica/2013/04/1255832-leia-a-transcricao-da-entrevista-de-marcofeliciano-a-folha-e-ao-uol---parte-1.shtml. Acesso em 7 de novembro de 2018.

Vol. 02, N. 04, Out. - Dez., 2019 - www.revistas.unilab.edu.br/index.php/rebeh 
implementar suas ações e programas de forma mais "tímida". Apesar disso, tivemos um processo de relativa continuidade, com a realização da $2^{\text {a }}$ Conferência Nacional LGBT, em 2011; a publicação dos Relatórios sobre Violência Homofóbica no Brasil (2011 e 2012); a criação do Sistema Nacional de Promoção de Direitos e Enfrentamento à Violência Contra LGBT, em 2013, e da Comissão Interministerial de Enfrentamento à Violência Contra LGBT, em 2015; além da publicação de outras portarias e ações menores.

Nesta conjuntura, as eleições de 2014 foram marcadas por um cenário extremamente polarizado, após a vitória de Dilma no segundo turno com pouco mais de $51 \%$ dos votos válidos - contra Aécio Neves (PSDB/MG), que, ao questionar a veracidade dos números apresentados, abriu caminhos para a construção de ações pelo impeachment. É importante notarmos que Dilma Rousseff intensificou, em seu segundo mandato, a aliança com setores conservadores da sociedade, tendo como principal reflexo as suas escolhas ministeriais. Tivemos, como exemplo, a nomeação de Kátia Abreu (PMDB/TO), da bancada do agronegócio, para o Ministério da Agricultura; de Gilberto Kassab (PSD/SP), ex-prefeito de São Paulo conhecido por favorecer a ampliação da especulação imobiliária em seu mandato, para o Ministério das Cidades; e de Joaquim Levy, economista neoliberal e nome forte do mercado financeiro, para o Ministério da Fazenda.

Se neste primeiro momento os protestos contra o governo eram esvaziados e a possibilidade de um impeachment era quase nula, a partir de 2016 presenciamos uma brusca mudança de cenário. Com a intensificação da cobertura midiática sobre o andamento das investigações da Lava Jato, que já alcançavam o alto escalão do Governo Federal, e o aprofundamento da crise econômica, os protestos pró-impeachment começaram a ganhar força, tomando proporções massivas em 13 de março de 2016. A partir deste momento, o cenário nacional passou a se tornar cada vez mais polarizado e importantes setores das elites econômicas e políticas iniciaram o esvaziamento do governo - que buscou apoio e sustentação nos movimentos sociais e populares que acompanharam a trajetória do Partido dos Trabalhadores (PT) ao longo de sua história, dentre os quais, os movimentos LGBT (CRUZ, 2015; TOITIO, 2016).

Antes da transição governamental, tivemos ainda a execução de duas ações direcionadas aos direitos LGBT, apresentadas de forma simbólica há poucos dias da queda do governo: (I) a realização da $3^{\text {a }}$ Conferência de Políticas Públicas e Direitos Humanos de LGBT, de 24 a 27 de abril de 2016, dentro das Conferências Conjuntas de Direitos Humanos; e (II) a publicação do decreto $\mathrm{n}^{\circ} 8.727$, de 28 de abril, que dispõe sobre o uso do nome social e o reconhecimento da 
identidade de gênero de travestis e transexuais no âmbito da administração pública federal. Assim terminavam quase quinze anos de governos petistas, com Dilma Rousseff sinalizando, para sua a base social, o compromisso com a pauta dos direitos humanos e dos direitos sexuais, lapesar de transcorridos quase seis anos de uma dinâmica de avanços e retrocessos no campo dos direitos LGBT - em confluência com o contraditório modus operandi petista de construção de amplas alianças políticas como forma de garantia da governabilidade.

\section{Políticas sexuais e o Governo Federal no Brasil pós-impeachment: breves comentários}

O processo do impeachment de 2016, caracterizado por diversos grupos como um golpe institucional (JINKINGS; DORIA; CLETO, 2016), foi marcado pelo protagonismo de um tipo bastante específico de conservadorismo brasileiro; no caso, um conservadorismo cristão que alia pautas econômicas e socioculturais em uma agenda política de propagação de pânicos morais (ARAGUSUKU, 2018; MISKOLCI; CAMPANA, 2017). Um tipo de conservadorismo que ganhou terreno recentemente no país (podemos delimitar os últimos quinze anos) e que teve seu ápice nos últimos cinco, principalmente como uma oposição política à agenda de direitos humanos e direitos sexuais. Neste sentido, ganharam visibilidade e destaque figuras políticas como o então deputado federal e atual presidente Jair Bolsonaro (PSL/RJ), o deputado Pastor Marco Feliciano (PODE/SP), o ex-senador Magno Malta (PR/ES) e o ex-senador, e atual prefeito do Rio de Janeiro, Marcelo Crivella (PRB/RJ), além do ex-deputado federal Eduardo Cunha $(\mathrm{PMDB} / \mathrm{RJ})$, um dos principais articuladores do impeachment na figura de Presidente da Câmara dos Deputados.

A transição governamental, com a chegada de Michel Temer (PMDB) na Presidência da República, confirmou os temores de militantes e de analistas em políticas LGBT: o governo Temer representou um recuo na agenda LGBT do Governo Federal, principalmente pela correlação interna de forças da nova coalizão governamental, condicionada pelo forte apoio e protagonismo das bancadas conservadoras no processo de impeachment. Relembrando que, logo após o seu discurso de posse, ainda como presidente interino, em 12 de maio de 2016, Temer se encontrou com lideranças religiosas, onde rezou e pediu a bênção de Deus para o seu novo governo, sendo também abençoado pessoalmente pelo Pastor Silas Malafaia, da 
Assembleia de Deus (Vitória em Cristo) ${ }^{10}$ - figura pública controversa, bastante conhecida por suas agressivas declarações contra os grupos LGBT.

Concomitantemente, a lista de ministros apresentada naquele dia também causou grande polêmica, pois apenas foram nomeados homens brancos para compor a sua equipe ministerial, Sendo o primeiro governo, desde o presidente Ernesto Geisel (1974-1979) em plena Ditadura Civil-Militar, a não incluir mulheres - ironicamente, isto ocorria após o impeachment da primeira presidenta do Brasil. Em relação às mudanças ministeriais, o Ministério das Mulheres, da Igualdade Racial, da Juventude e dos Direitos Humanos foi desfeito e substituído pela Secretaria de Direitos Humanos, alocado no novo Ministério da Justiça e Cidadania, onde se rearticulou a Coordenação Geral de Promoção dos Direitos LGBT.

O Governo de Temer (2016-2018) impôs uma forte agenda de austeridade fiscal para o país, buscando responder à crise econômica que se instaurou a partir de 2015. A primeira medida de grande impacto ocorreu em 15 de dezembro de 2016, com a promulgação da Emenda Constitucional n ${ }^{\circ}$ 95/20116, proposta pelo Governo Federal - intitulada de PEC do "teto dos gastos" em sua passagem pelo Congresso Nacional. Tal medida limitou a utilização de verba pública pelos próximos vinte anos, congelando investimentos em áreas sociais estratégicas, como saúde, assistência social e educação (MARQUES; UGINO, 2017). Em 2017, o governo se centrou na aprovação das reformas da previdência e trabalhista, iniciando um intenso processo de negociação com as lideranças partidárias. Com um Congresso Nacional bastante polarizado, a reforma trabalhista foi aprovada e sancionada em junho como Lei n. ${ }^{\circ}$ 13.467/2017, e aceleraram-se as negociações para a aprovação da reforma da previdência.

Tais reformas provocaram uma forte reação das centrais sindicais e de diversos movimentos sociais, que realizaram, ao longo de 2017, massivas manifestações em todo o país; como a greve geral que paralisou o país no dia 28 de abril. Cabe destacar que tivemos naquele ano, como um evento significativo, as manifestações e atividades do dia 8 de março, o Dia Internacional das Mulheres. Tais eventos - alinhados à chamada por uma Greve Internacional das Mulheres (International Women's Strike), protagonizada por lideranças feministas de todo o mundo - impulsionaram uma reunificação de distintos movimentos feministas brasileiros em torno da luta comum contra as reformas propostas pelo governo Temer. No entanto, no segundo semestre deste ano, tais mobilizações sociais passaram por um significativo refluxo, decorrente

\footnotetext{
${ }^{10}$ Extra (05/2016), "Malafaia faz oração com Temer após discurso de posse: 'Para Deus Abençoar o Brasil'”. Disponível em: https:/extra.globo.com/noticias/brasil/malafaia-faz-oracao-com-temer-apos-discurso-de-possepara-deus-abencoar-brasil-19296009.html. Acesso em 12 de junho de 2018.

Vol. 02, N. 04, Out. - Dez., $2019 \cdot$ www.revistas.unilab.edu.br/index.php/rebeh
} 
em parte das dificuldades na construção de um consenso em relação às estratégias que seriam utilizadas para o fortalecimento da oposição ao governo e para as eleições de 2018.

Apesar de sua grande fragilidade em relação à opinião pública e sua instabilidade política, o governo Temer se sustentou na agenda socioeconômica mais conservadora do grande empresariado brasileiro. Certamente, esta classe social apostou na capacidade do governo em executar reformas neoliberais, tais como a ampliação das privatizações, o congelamento de gastos e a diminuição do aparelho estatal, junto ao fortalecimento de processos de mercantilização da sociedade, capazes de aprofundar a lógica de "acumulação por espoliação" que fortalece economicamente as elites financeiras (HARVEY, 2007, 2011). A continuidade de seu governo, mesmo após graves escândalos de corrupção e o pior índice de aprovação popular da história do Brasil, explica-se, em parte, à forte sustentação política que Temer logrou nas elites defensoras dessa agenda político-econômica.

No campo das políticas de cidadania LGBT, o Governo Federal de Temer não trabalhou a partir de uma política de "terra arrasada" (ou seja, de desmontes e mudanças radicais), assim como fez no campo dos direitos sociais e trabalhistas. Em certa medida, isto se refletiu na avaliação relativamente "positiva" feita pelo Guia Gay de São Paulo - conhecido portal virtual de notícias LGBT - em dezembro de 2016, na notícia "Dilma sai. Temer entrou. Houve diferença na pauta LGBT?" "11. Nesta matéria, o portal elencou alguns critérios de comparação entre os governos Dilma e Temer, apresentando-os como governos bastante similares. Apesar da matéria dar ênfase e supervalorizar as ações do governo Temer, aparentemente em um movimento de apoio ou aprovação política do governo, é inegável a manutenção de algumas ações e políticas de cidadania LGBT promovidas pelos governos petistas.

Ao longo de seu primeiro ano, em 2016, o governo Temer não revogou uma única medida aprovada pelos governos anteriores no campo das políticas sexuais. Em detrimento a um desmonte aberto destas políticas, assim como ansiavam os grupos conservadores mais radicalizados, compreendemos que o governo buscou invisibilizar as ações e programas da agenda LGBT em andamento, inviabilizando a sua execução a partir do congelamento de recursos. Desse modo, o recuo destas políticas foi aplicado de forma sutil e gradual, sem a provocação de grandes alardes ou ações governamentais mais bruscas. Se por um lado, ao longo dos governos petistas, as políticas LGBT se constituíram enquanto uma "política de governo" (sem um amparo jurídico e legislativo sólido), apresentando uma fragilidade institucional e uma

\footnotetext{
${ }^{11}$ Guia Gay de São Paulo (2016), “Dilma sai. Temer entrou. Houve diferença na pauta LGBT?”, disponível em: http://www.guiagaysaopaulo.com.br/1/n--dilma-saiu.-temer-entrou.-houve-diferenca-na-pauta-lgbt--25-12-2016-3651.htm. Acesso em 10 de dezembro de 2017.

Vol. 02, N. 04, Out. - Dez., 2019 - www.revistas.unilab.edu.br/index.php/rebeh
} 
instabilidade operativa. Por outro lado, fica evidente a sua consolidação na agenda pública e na arena política, ganhando alguns aspectos de "política de Estado", pois a despeito das transições de governo e de seu caráter político-ideológico, tais políticas se mantiveram na pauta governamental ${ }^{12}$.

Concomitantemente, o governo foi fortemente tensionado por sua base parlamentar conservadora, que demandava a retirada da agenda LGBT da pauta do governo e a revogação das ações implementadas pelos governos anteriores. Como relatado pelo deputado federal Sóstenes Cavalcante (DEM/RJ) - após uma reunião da Presidência da República, em 6 de abril de 2017, com alguns deputados representantes das frentes evangélica, católica, antidrogas e em defesa da vida do Congresso Nacional - o "presidente disse que pessoalmente sempre está alinhado com os nossos pensamentos e que jamais defenderia a legalização do aborto ou algum desses temas, mas que iria encaminhar à equipe técnica os nossos pleitos"13. No mesmo dia, logo após essa reunião, o Ministério da Educação (MEC) apresentou a nova e terceira Base Nacional Comum Curricular (BNCC) sem os termos "orientação sexual" e "identidade de gênero", contrariando a versão preliminar e atendendo aos pedidos de lideranças conservadores que acusavam o documento de promover a "ideologia de gênero" e a agenda LGBT (ARAGUSUKU, 2018).

Esta posição de alinhamento do governo com o pensamento conservador se evidenciou também no discurso oficial do presidente no Dia Internacional da Mulher, em 8 de março de 2017. Em seu pronunciamento, fazendo referência a sua esposa Marcela Temer, o presidente reconheceu a "importância" da mulher para os cuidados domésticos do lar e afirmou que a mulher/esposa seria a única pessoa realmente qualificada para a educação dos filhos, dizendo também (de forma humorada) que "ela é capaz de indicar os desajustes de preços em supermercados e identificar flutuações econômicas no orçamento doméstico"14. O discurso presidencial - que teve uma forte repercussão midiática, inclusive internacional - foi duramente

\footnotetext{
${ }^{12}$ Logicamente, as políticas LGBT estão longe de se tornar uma "política de Estado" na acepção estrita do termo, com o Estado brasileiro em sua integridade reconhecendo a relevância pública desta temática - ou seja, implementação pelo Poder Executivo, aprovação pelo Legislativo e sustentação pelo Judiciário (não necessariamente nesta ordem). Em nível federal no Brasil, temos um histórico de avanços em políticas LGBT vinculado aos poderes Executivo e Judiciário, enquanto que o Legislativo se mantém fechado à aprovação de legislações favoráveis.

${ }^{13}$ O Globo (2017), "Bancada Religiosa pediu a Temer retirada de questão de gênero da Base", disponível em: https://oglobo.globo.com/sociedade/educacao/bancada-religiosa-pediu-temer-retirada-de-questao-de-genero-dabase-21179389. Acesso em 5 de maio de 2018.

${ }_{14}$ Pronunciamento completo em vídeo no portal da Globo News (03/2017), "Discurso de Temer no Dia Internacional da Mulher repercute nas redes sociais". Disponível em: http://g1.globo.com/globo-news/estudio$\mathrm{i} /$ videos/v/discurso-de-michel-temer-no-dia-internacional-da-mulher-repercute-nas-redes-sociais/5712001/.

Acesso em 7 de julho de 2017.

Vol. 02, N. 04, Out. - Dez., 2019 · www.revistas.unilab.edu.br/index.php/rebeh
} 
criticado, inclusive por setores que apoiavam o governo, sendo entendido por algumas análises como um deslize, uma falta de "gingado" político e carisma do presidente. No entanto, podemos compreendê-lo como uma estratégia de aproximação do governo com o discurso religioso conservador, visando a sua sustentação a partir do apoio de determinados setores da população brasileira.

O governo buscou simultaneamente jogar com ambos os lados (conservadores e progressistas), abrindo espaços, ainda que limitados, para a formulação e aplicação de políticas de direitos humanos. Isto provavelmente ocorreu pelas pressões existentes no âmbito da comunidade internacional, em relação ao marco de direitos humanos estabelecidos por organismos como a Organização das Nações Unidas. Certamente, o governo Temer buscou se esquivar do rótulo de "violador de direitos humanos" - algo que seria considerado um retrocesso em relação aos governos petistas, reconhecidos internacionalmente por seus programas sociais e suas políticas de direitos humanos. Uma outra leitura que pode ser realizada é que esse jogo mútuo seria uma forma de sustentação da ampla coalizão governamental, que absorveu algumas lideranças "progressistas" sob uma narrativa de reconstrução nacional e retomada do desenvolvimento econômico.

Logo nos primeiros momentos, na nomeação ministerial de maio de 2016, tivemos a indicação do primeiro ministro abertamente gay, Marcelo Calero (PSDB/RJ), para um cargo do alto escalão federal. Em maio de 2016, Calero foi nomeado chefe da Secretaria de Cultura, vinculada ao Ministério da Educação (MEC). Após a emergência de protestos de movimentos de cultura em todo o país, com a ocupação das sedes do extinto Ministério da Cultura (MinC), o governo recuou, e em poucos dias restabeleceu o MinC, mantendo Calero em sua chefia ${ }^{15}$. Também neste primeiro momento, Flávia Piovesan, procuradora do Estado de São Paulo e acadêmica reconhecida no campo dos direitos humanos, foi nomeada para chefiar a Secretaria de Direitos Humanos; e Luislinda Valois (na época, PSDB/BA), desembargadora aposentada e uma das primeiras juízas negras do país, para a Secretaria de Promoção da Igualdade Racial ambas vinculadas ao novo Ministério da Justiça e da Cidadania. Como uma subpasta da Secretaria de Direitos Humanos, tivemos a nomeação de Marina Reidel, primeira mulher transexual a ser titulada como mestra, como coordenadora-geral da Promoção dos Direitos LGBT. Neste caso, o governo optou pela manutenção da representatividade trans na gestão das

\footnotetext{
${ }^{15}$ No dia 18 de novembro de 2016, Marcelo Calero pediu demissão do MinC, afirmando que possui divergências com o andamento do governo. Filiado ao PPS desde 2018, foi eleito deputado federal nas eleições de 2018 - sendo um dos três únicos parlamentares LGBT da 56 ${ }^{\mathrm{a}}$ Legislatura (2019-2023).

Vol. 02, N. 04, Out. - Dez., 2019 · www.revistas.unilab.edu.br/index.php/rebeh
} 
políticas LGBT, anteriormente chefiada por Symmy Larrat - primeira travesti a comandar uma pasta do Governo Federal, empossada durante o governo Dilma.

Também em relação à questão dos direitos humanos, em meio à crise dos presídios no Brasil, iniciada nos primeiros dias de 2017, com a ocorrência de rebeliões consecutivas e massacres no interior de presídios, o governo optou pelo fortalecimento de sua política de direitos humanos. Assim, no dia 3 de fevereiro, presenciamos a recriação do Ministério dos Direitos Humanos, com a posse de Luislinda Valois como ministra, respondendo também às críticas direcionadas à falta de representatividade feminina e negra na equipe ministerial.

Em síntese, podemos apresentar que o governo Temer - que nasceu de um golpe parlamentar protagonizado por grupos conservadores - não possuía legitimidade e base popular de sustentação, se mantendo a partir do apoio de uma maioria parlamentar acuada por numerosas investigações de corrupção, de uma minoria ultraconservadora que buscava avançar sobre as políticas de direitos humanos, e por setores das elites que apostavam na aplicação da agenda de reformas neoliberais. Neste sentido, sobreleva-se a face antipopular do governo Temer, que buscou atender as demandas das elites políticas e econômicas para a manutenção de seus privilégios, debilitando as frágeis estruturas democráticas do Estado brasileiro e potencializando o crescimento de desigualdades sociais. Já em meados de 2017, Temer apresentaria o pior índice de popularidade já registrado desde a redemocratização; no entanto, apesar dos momentos de crise, o governo se manteve até o ano de 2018 e a instauração do processo eleitoral.

Um dado integrante é que o governo Temer intensificou, em 2018, a pauta dos direitos humanos para as populações LGBT, mesmo com o momento de crescimento do conservadorismo político no cenário nacional e o clima de polarização política instaurado pela proximidade das eleições presidenciais. Entretanto, manteve-se uma certa continuidade a linha política anterior: as políticas de cidadania LGBT não se constituíam enquanto uma prioridade na agenda governamental e, apesar de existirem programas e ações em andamento, dificilmente ocorreria a consolidação de políticas mais efetivas. Cabe lembrar que as políticas LGBT continuavam a receber grande oposição das bancadas conservadoras no Congresso Nacional, que se mobilizavam em torno do discurso de combate à "ideologia de gênero".

Em 2018 foram duas ações de maior impacto que receberam uma grande visibilidade midiática. A primeira, o lançamento do Pacto Nacional de Enfrentamento à Violência LGBTfóbica, em maio de 2018, por meio de portaria assinada pelo Ministro dos Direitos Humanos - o jurista Gustavo do Vale Rocha, que substituiu Luislinda Valois, com a saída do 
PSDB da base do governo. O Pacto, que depende da adesão dos governos estaduais, prevê a articulação de ações entre o Governo Federal e os governos estaduais no combate à LGBTfobia, visando a construção de uma rede integrada nacionalmente (BRASIL, 2018). Posteriormente, ém julho, o presidente assinou o decreto de convocatória da $4^{\mathrm{a}}$ Conferência Nacional de Políticas Públicas e Direitos Humanos LGBT, com previsão de realização no ano seguinte, em 2019, dando sinalizações de compromisso futuro com a temática dos direitos humanos e a agenda LGBT. Vale destacar também as polêmicas em torno do Exame Nacional do Ensino Médio (ENEM), realizado em novembro de 2018, que foi repudiado por grupos e lideranças conservadoras por possuir perguntas que faziam referências à comunidade LGBT.

Por outro lado, neste último período, também presenciamos graves retrocessos em torno da cidadania LGBT, como a decisão de um juiz da $14^{\text {a }}$ Vara Federal do Distrito Federal em permitir que psicólogos/as tratem pacientes com “orientação sexual egodistônica", suspendendo a Resolução 01/99 do Conselho Federal de Psicologia (CFP) que proíbe a patologização da homossexualidade, em setembro de 2017 (o caso tramita na justiça); e a aprovação de diversas leis municipais que proíbem a "ideologia de gênero" nas escolas públicas, algumas autônomas, outras vinculados aos projetos municipais do Escola Sem Partido (MIGUEL, 2016). Apesar das instâncias superiores do Judiciário sinalizarem o suporte às demandas por direitos LGBT (por exemplo, algumas legislações aprovadas foram suspensas pelo STF) tais eventos demonstram que o poder de influência de grupos conservadores cresce nas instituições públicas e nas disputas presentes no seio da sociedade civil.

A vitória de Jair Bolsonaro nas eleições presidenciais e o crescimento dos grupos de extrema-direita no Congresso Nacional, com destaque para o seu partido, o PSL, que conseguiu a segunda maior bancada da Câmara, certamente reforçam esta tendência de retrocessos e de recuos na agenda de direitos e cidadania LGBT implementada no Brasil. Lembrando que sua campanha eleitoral teve como um dos principais pontos a denúncia do "kit gay" implementado por Haddad (PT) quanto era Ministro da Educação do governo Dilma - afirmação considerada inverídica e punida pelo Tribunal Superior Eleitoral (TSE) - e o combate à "ideologia de gênero" em todas as instâncias do Governo Federal.

\section{Considerações finais}

Como relatado neste artigo, as políticas de cidadania LGBT adentraram na agenda do Governo Federal desde meados dos anos de 1990, acompanhando o crescimento da relevância 
desta temática nos debates públicos e das organizações de movimentos LGBT em todo o país. No entanto, após quase vinte anos de avanços político-institucionais, com a implementação de programas e ações em termos de políticas públicas, tivemos uma rearticulação de grupos conservadores, que iniciaram um processo de forte oposição a tais políticas em espaços da sociedade civil e, principalmente, nas discussões legislativas do Congresso Nacional sobretudo na Câmara dos Deputados a partir da 54 ${ }^{\mathrm{a}}$ Legislatura (2011-2015).

Enquanto o Governo FHC (1995-2002) abriu espaços mínimos para o avanço de políticas de combate à discriminação contra pessoas LGBT na administração pública federal, dentro da esfera da promoção de direitos humanos; o Governo Lula (2003-2010) ampliou tais políticas, transformando-as em uma agenda de governo, com a concretização de uma série de ações e programas. Por outro lado, o Governo Dilma (2011-2016) marcou um período de tensões e retrocessos nesta agenda governamental, dada a dificuldade do governo em gestionar os antagonismos de sua base conservadora com as demandas LGBT. A partir de 2011, fortaleceu-se na Câmara dos Deputados uma bancada conservadora cristã (evangélica e católica), pressionando o governo a congelar ações em andamento, como o marcante caso dos materiais do programa Escola Sem Homofobia, intitulado de "kit gay" por grupos e lideranças conservadoras.

Após o impeachment, o Governo Temer (2016-2018) ampliou o diálogo e abriu importantes espaços políticos para as bancadas conservadoras mais radicalizadas, em especial à bancada evangélica; no entanto, apesar da amplificação dos retrocessos já presentes desde o governo anterior, manteve as políticas LGBT como uma pauta fundamental de sua agenda de direitos humanos. Mesmo com o avanço do conservadorismo político no cenário nacional e a crescente desmoralização das políticas LGBT a partir das denúncias contra a "ideologia de gênero", o Governo Temer publicou um novo programa na área (o Pacto Nacional LGBT) e convocou a $4^{\text {a }}$ Conferência Nacional para o ano de 2019.

Apesar do processo eleitoral de 2018 ultrapassar o escopo desta análise, podemos apresentar que a vitória de Jair Bolsonaro (PSL) à Presidência da República, sustentada também por discursos antagônicos aos direitos sexuais LGBT, não se configurou como "um raio em céu azul”; ou seja, como algo inesperado. Conforme analisadas tanto as políticas socioeconômicas, quanto as políticas sexuais antes e após do impeachment, fez-se evidente a consolidação de um renovado conservadorismo político no Brasil, que alinha pautas econômicas e sociais em uma narrativa vinculada à promoção de pânicos morais. Neste cenário, as disputas em torno das 
políticas sexuais e os retrocessos marcantes no campo da cidadania LGBT foram importantes aspectos da conjuntura nacional que perpassaram a década de 2010 como um todo.

Entretanto, o recém empossado Governo Bolsonaro (2019- ), a despeito de uma forte Yretórica anti-LGBT, não aplicou de forma imediata o seu programa eleitoral, mantendo algumas políticas LGBT no âmbito de sua administração - em meio a retrocessos graduais, como a retirada de cartilhas LGBT e de educação sexual de páginas virtuais oficiais. O governo optou pela manutenção de uma Diretoria de Promoção de Direitos LGBT, vinculada ao Ministério da Mulher, da Família e dos Direitos Humanos, agora chefiado pela pastora Damares Alves, alinhada com a bancada evangélica e com a retórica conservadora. Logicamente, o governo mantém seu posicionamento de confronto às pautas LGBT, e vem referendando o discurso da "ideologia de gênero" enquanto uma posição oficial do Governo Federal. Como dito pelo próprio presidente em seu discurso de posse no Congresso Nacional: "Vamos unir o povo, valorizar a família, respeitar as religiões e nossa tradição judaico-cristã, combater a ideologia de gênero, conservando nossos valores. O Brasil voltará a ser um país livre de amarras ideológicas"16.

Ao "sexualizar" as narrativas sobre a "grande política" que em geral não versam sobre a política sexual, pudemos destacar como, durante o processo de crise política, a cidadania LGBT seguiu como uma cidadania precária e instável (BENTO, 2014) junto ao desmonte ou o congelamento das frágeis ações governamentais em curso desde meados dos anos de 1990. Embora a pauta LGBT tenha se consolidado no debate público e se tornado um tema central nas discussões sobre os direitos humanos, frente ao fortalecimento de políticas neoliberais e sob uma racionalidade neoliberal cada vez mais alinhada ao conservadorismo político, reafirmou-se na atualidade uma "cidadania de consolação" (OLIVEIRA, 2013) para as populações LGBT.

Gostaríamos de finalizar este texto lembrando que a primeira mulher bissexual, negra e moradora da Favela da Maré, a ser eleita na Câmara Municipal do Rio de Janeiro, Marielle Franco (PSOL/RJ), foi brutalmente assassinada em março de 2018. E que o primeiro deputado federal militante LGBT, Jean Wyllys (PSOL/RJ), optou por sair do país, em janeiro de 2019, por medo das constantes ameaças de morte que vinha sofrendo. Estes fatos políticos, certamente, refletem parte do atual cenário político brasileiro, marcado por constantes violações

16 O Globo (01/2019), “Confira na íntegra do discurso de Jair Bolsonaro no Congresso". Disponível: <https://oglobo.globo.com/brasil/confira-integra-do-discurso-de-jair-bolsonaro-no-congresso-23339328>.

Acesso em: 10 fev 2019.

Vol. 02, N. 04, Out. - Dez., 2019 - www.revistas.unilab.edu.br/index.php/rebeh 
de direitos humanos e pela legitimação de discursos de ódio, dificultando a consolidação de uma cidadania LGBT no país.

\section{RᄃBEF}

\section{Referências}

ALMEIDA, R. A onda quebrada - evangélicos e conservadorismo. Cadernos Pagu, n. 50, s./p., 2017.

ANDERSON, P. Lula's Brazil. London Review of Books, v. 33, n. 7, p. 3-12, mar. 2011.

ARAGUSUKU, H. A. O discurso da "ideologia de gênero" na Câmara dos Deputados: análise crítico-discursiva e psicopolítica. Dissertação (Mestrado em Ciências) - Instituto de Psicologia, Universidade de São Paulo, São Paulo, 2018.

ARAGUSUKU, H. A.; LOPES, M. A. S. Preconceito, Discriminação e Cidadania LGBT: Políticas Públicas em Mato Grosso e no Brasil. Revista ACENO, v. 3, n. 5, p. 242-258, 2016.

ARAGUSUKU, H. A.; LOPES, M. A. S. Políticas públicas e cidadania LGBT em Mato Grosso: uma década de avanços e retrocessos (2007-2017). Sexualidad, Salud y Sociedad, n. 29, p. 147-171, 2018.

BENTO, B. Nome social para pessoas trans: cidadania precária e gambiarra legal. Contemporânea, v. 4, n. 1, p. 165-182, 2014.

BRASIL. Presidência da República. Programa Nacional de Direitos Humanos. Brasília: Governo Federal, 1996.

BRASIL. Ministério da Justiça. Secretaria de Estado dos Direitos Humanos. Programa Nacional de Direitos Humanos - PNDH II. Brasília: SEDH, 2002.

BRASIL. Ministério dos Direitos Humanos. Portaria n⿳ 202, de 10 de maio de 2018. Institui o Pacto Nacional de Enfrentamento à Violência LGBTfóbica. Brasília: MDH, 2018. Disponível em: <https://www.mdh.gov.br/biblioteca/lgbt/portaria-no-202-2018-institui-o-pacto-nacionalde-enfrentamento-a-violencia-lgbtfobica/view>. Acesso em 10 out 2018.

BUTLER, J. O parentesco é sempre tido como heterossexual?. Cadernos Pagu, n. 21, p. 219$260,2003$.

BUTLER, J. Problemas de Gênero: feminismo e subversão da identidade. Rio de Janeiro: Civilização Brasileira, 2015.

BUTLER, J. Corpos em aliança e a política das ruas: notas para uma teoria performativa de assembleia. Rio de Janeiro: Civilização Brasileira, 2018.

CARRARA, S. Políticas e direitos sexuais no Brasil contemporâneo. Bagoas, v. 4, n. 5, p. 131$148,2010$.

Vol. 02, N. 04, Out. - Dez., $2019 \cdot$ www.revistas.unilab.edu.br/index.php/rebeh 
CARRARA, S. Moralidades, Racionalidades e Políticas Sexuais no Brasil Contemporâneo. Mana, v. 21, n. 2, p. 323-345, 2015.

CARRARA, S.; VIANNA, A. R. B. Políticas sexuales y derechos sexuales en Brasil: estudio de caso. In: PARKER, R.; PETCHESKY, R.; SEMBER, R. (Org.). Políticas sobre sexualidad: Reportes desde las líneas del frente. Sexuality Policy Watch, 2008. Disponível em: $<$ https://sxpolitics.org/es/wp-content/uploads/sites/3/2016/03/sexpolitics-en.pdf $>$. Acesso em 10 mai 2017.

CRUZ, R. R. Do protesto às urnas: o movimento homossexual brasileiro na transição política (1978-1982). Dissertação (Mestrado em Ciências Sociais) - Escola de Filosofia, Letras e Ciências Humanas, Universidade Federal de São Paulo, São Paulo, 2015.

ANIS. Instituto de Bioética, Direitos Humanos e Gênero e Associação Lésbica Feminista de Brasília Coturno de Vênus. Legislação e Jurisprudência LGBTTT. Brasília: Secretaria Especial de Direitos Humanos, 2007.

CONNELL, R. The State, Gender, and Sexual Politics: Theory and Appraisal. Theory and Society, v. 19, n. 5, p. 507-544, 1990.

DARDOT, P.; LAVAL, C. A nova razão do mundo: ensaio sobre a sociedade neoliberal. São Paulo: Boitempo, 2016.

DEFAGO, M. A. P.; FAÚNDES, J. M. M.; VAGGIONE, J. M. Religious conservatism on the global stage: threats and challenges for LGBTI rights. Global Philanthropy Project, 2018. Disponível em: $<$ https://globalphilanthropyproject.org/2018/11/04/religious-conservatism-onthe-global-stage-threats-and-challenges-for-lgbti-rights/>. Acesso em: 6 jan 2019.

FACCHINI, R. Sopa de letrinhas? Movimento homossexual e produção de identidades coletivas nos anos 90. Rio de Janeiro: Garamond, 2005.

FIGARI, C.@s “outr@s” cariocas: interpelações, experiências e identidades homoeróticas no Rio de Janeiro: séculos XVII ao XX. Belo Horizonte: Editora UFMG, 2007.

FRACCAROLI, Y.; HEINZELMANN, F.L. Fin de la historia? La disputas por el concepto de género en Brasil Contemporáneo. Anales electrónicos XIII Jornadas Nacionales Historia de Mujeres/VIII Congreso Iberoamericano de Estudios de Género, p. 1-12, 2018. Disponível em: $\quad<\underline{\text { http://eventosacademicos.filo.uba.ar/index.php/JNHM/XIII-VIII- }}$ 2017/paper/view/3592>. Acesso em: 13 mar 2017.

FRASER, N. The End of Progressive Neoliberalism. Dissidente Magazine, 2 jan. 2017. Disponível em: <https://www.dissentmagazine.org/online articles/progressive-neoliberalismreactionary-populism-nancy-fraser>. Acesso em: 13 mar 2017.

GREEN, J. N. Além do Carnaval: a homossexualidade masculina no Brasil do século XX. São Paulo: Editora UNESP, 2000.

GREEN, J. N.; POLITO, R. Frescos trópicos: fontes sobre homossexualidade masculina no Brasil (1870-1980). Rio de Janeiro: José Olympio Editora, 2006.

Vol. 02, N. 04, Out. - Dez., 2019 - www.revistas.unilab.edu.br/index.php/rebeh 
GURZA LAVALLE, A.; SZWAKO, J. Sociedade civil, Estado e autonomia: argumentos, contra-argumentos e avanços no debate. Opinião Pública, v. 21, n. 1, p. 157-187, 2015.

HARAWAY, D. Saberes localizados: a questão da ciência para o feminismo e o privilégio da perspectiva parcial. Cadernos Pagu, n. 5, p. 7-41, 1995.

HARVEY, D. A brief history of neoliberalism. Oxford: Oxford University Press, 2007.

HARVEY, D. O enigma do capital: e as crises do capitalismo. São Paulo: Boitempo, 2011.

IGBE. Instituto Brasileiro de Geografia e Estatística. Contas Nacionais Trimestrais. Indicadores de Volumes e Valores Correntes: Outubro/Dezembro 2016. Brasília: IGBE: 2017.

Disponível

em:

$<$ ftp://ftp.ibge.gov.br/Contas Nacionais/Contas Nacionais Trimestrais/Fasciculo Indicadore s_IBGE/pib-vol-val_201604caderno.pdf > . Acesso em: 10 fev 2018.

IRINEU, B. A. Homonacionalismo e cidadania LGBT em tempos de neoliberalismo: dilemas e impasses às lutas por direitos sexuais no Brasil. Revista Em Pauta, v. 12, n. 34, p. 155-178, 2014.

IRINEU, B. A. Exercendo a "crítica lesbofálica" às demandas por uma "cidadania LGBT" no contexto brasileiro (2003-2016). Periódicus, v. 7, n. 1, p. 78-101, 2017.

JINKINGS, I.; DORIA, K.; CLETO, M. (Org.). Por que gritamos golpe?: Para entender o impeachment e a crise política no Brasil. São Paulo: Boitempo, 2016.

JUNQUEIRA, R. D. "Ideologia de gênero": a gênese de uma categoria política reacionária ou: a promoção dos direitos humanos se tornou uma "ameaça à família natural"?. In: RIBEIRO, P. R. C.; MAGALHÃES, J. C. (Org.). Debates contemporâneos sobre educação para a sexualidade. Rio Grande, RS: Editora da FURG, 2017.

KOVÁTS, E; PÕIM, M. (Org.). Gender as symbolic glue: the position and role of conservative and far right parties in the anti-gender mobilizations in Europe. Berlin: Foundation for European Progressive Studies \& Friedrich Ebert Stiftung, 2015.

LOURO, G.L. Gênero e sexualidade: pedagogias contemporâneas. Pro-posições, v. 19, n. 2, p. 17-23, 2008.

MACHADO, F. V. Do Estatal à Política: uma análise psicopolítica das relações entre o Estado e os movimentos de juventude e LGBT no Brasil (2003-2010). Tese (Doutorado em Psicologia) - Faculdade de Filosofia e Ciências Humanas, Universidade Federal de Minas Gerais, Belo Horizonte, 2013.

MACHADO, M. D. C. Aborto e ativismo religioso nas eleições de 2010. Revista Brasileira de Ciência Política, n. 7, p. 25-54, 2012.

MACHADO, M. D. C. O discurso cristão da "ideologia de gênero". Revista Estudos Feministas, v. 26, n. 2, p. 1-18, 2018. 
MACRAE, E. Afirmação da identidade homossexual: seus perigos e sua importância. In: MACRAE, E. A Construção da Igualdade: política e identidade homossexual no Brasil da Abertura. Salvador: EDUFBA, p. 67-75, [1987] 2018.

RE , n. 3, p. 8-23, set.-dez. 2018.

MELLO, L.; BRITO, W.; MAROJA, D. Políticas públicas para a população LGBT no Brasil: notas sobre alcances e possibilidades. Cadernos Pagu, n. 39, p. 403-429, 2012. Disponível em:

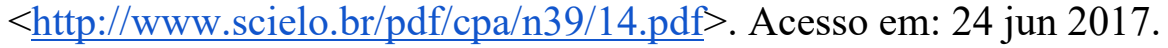

MELlO, L.; MAROJA, D.; BRITO, W. Políticas Públicas para a população LGBT no Brasil: um mapeamento crítico preliminar. Relatório de Pesquisa. Faculdade de Ciências Sociais, Universidade Federal de Goiás, Goiânia, 2010.

MIGUEL, F. L. Da "doutrinação marxista" à "ideologia de gênero" - Escola Sem Partido e as leis da mordaça no parlamento brasileira. Direito \& Práxis, v. 7, n. 15, p. 590-621, 2016.

MISKOLCI, R; CAMPANA, M. "Ideologia de gênero": notas para a genealogia de um pânico moral contemporâneo. Revista Estado e Sociedade, v. 32, n. 3, p. 735-747, set.-dez. 2017.

OLIVEIRA, F.; BRAGA, R.; RIZEK, C. (Org.). Hegemonia às avessas: economia, política e cultura na era da servidão financeira. São Paulo: Boitempo, 2010.

OLIVEIRA, J. M. Cidadania sexual sob suspeita: uma meditação sobre as fundações homonormativas e neo-liberais de uma cidadania de "consolação". Psicologia \& Sociedade, v. 25 , n. 1, p. 68-78, 2013.

PAULANI, L. O projeto neoliberal para a sociedade brasileira: sua dinâmica e seus impasses, In: LIMA, J. C. F.; NEVES, L. M. W. (Org.). Fundamentos da educação escolar do Brasil contemporâneo. Rio de Janeiro: Editora Fiocruz/EPSJV, 2006.

RAMOS, S.; CARRARA, S. A constituição da problemática da violência contra homossexuais: a articulação entre ativismo e academia na elaboração de políticas públicas. Physis, v. 16, n. 6, p. 185-205, 2006.

RAMOS, S.; PEREIRA JR., A. Disque Defesa Homossexual: Primeiro relatório. Rio de Janeiro: Secretaria de Segurança Pública. Disponível em: $<\underline{\text { https://www.ucamcesec.com.br/textodownload/disque-defesa-homossexual-ddh-primeiro- }}$ relatorio/>. Acesso em: 12 jan. 2018.

RUBIN, G. Thinking sex: Notes for a radical theory of the politics of sexuality. In: VANCE, C. (Ed.). Pleasure and Danger: exploring female sexuality. Boston: Routledge and Kegan Paul, 1984.

SCOTT, J. Gênero: uma categoria útil para a análise histórica. Educação e Realidade, v. 20, n. 2, 1995. 
TOITIO, R. Cores e contradições: A luta pela diversidade sexual e de gênero sob o neoliberalismo brasileiro. Tese (Doutorado em Ciências Sociais) - Instituto de Filosofia e Ciências Humanas, Universidade Estadual de Campinas, Campinas, 2016.

TREVISAN, J. S. Devassos no paraíso: a homossexualidade no Brasil, da colônia à atualidade. São Paulo: Editora Record, 2000.

VAINER, C. et al. Cidades rebeldes: Passe Livre e as manifestações que tomaram as ruas do Brasil. São Paulo: Boitempo, 2013.

VITAL, C.; LOPES, P. V. L. Religião e política: uma análise da atuação de parlamentares evangélicos sobre direitos das mulheres e de LGBTs no Brasil. Rio de Janeiro: Fundação Heinrich Böll, 2013.

WEEKS, J. Sex, Politics and Society: the regulation of sexuality since 1800. London: Longman, 1989.

WEEKS, J. Sexuality and its discontents: meanings, myths and modern sexualities. New York: Routledge and Kegan Paul, 2002.

\title{
STATE, SEXUAL POLITICS AND LGBT CITIZENSHIP IN POST- IMPEACHMENT BRAZIL
}

\begin{abstract}
This article has as main objective the construction of a conjunctural analysis about sexual policies in Brazil, with emphasis on LGBT citizenship policies in the scope of the Federal Government. Our narrative starts from a historical analysis of these policies, concentrating fundamentally on the period from 1996 to 2018, that is, from the moment of presentation of the first programs destined to the LGBT population by the Federal Government, to the current period of political and ideological transition of the governmental agenda in a postimpeachment Brazil. In theoretical-methodological terms, we performed a conjunctural analysis, linking fragmented and dispersed political events in an articulated narrative, relating concepts such as sexual politics and LGBT citizenship in the production of an analysis of the national political scenario. We sought, in that way, to highlight the main political facts that marked the relationship between the Brazilian State and the civil society in the field of sexual politics. It should be noted that this narrative did not conform as a finished or closed analysis, but rather as an analytical possibility that tries to bring new elements to reflect on the Brazilian socio-political context. On the other hand, it is a theoretical contribution to the field of studies in gender and sexuality, in specific, to the field of study on State and sexual policies.
\end{abstract}

Keywords: Sexual Politics; Gender; LGBT Citizenship; Federal Government.

Recebido em: 16/03/2019

Aceito em: 05/10/2019 